\title{
Development of a Dynamic Substance Flow Model of Zinc in Japan
}

\author{
Hiroshi TABAYASHI, Ichiro DAIGO, Yasunari MATSUNO and Yoshihiro ADACHI \\ Department of Materials Engineering, Graduate School of Engineering, The University of Tokyo, 7-3-1 Hongo, Bunkyo-ku, \\ Tokyo 113-8656 Japan.
}

(Received on January 19, 2009; accepted on April 4, 2009; originally published in Tetsu-to-Hagané, Vol. 94 (2008), No. 11, pp. 562-568)

\begin{abstract}
In this paper, a dynamic substance flow model of zinc in Japan was conducted. Currently, approximately $60 \%$ of zinc in Japan is used for galvanized steel (galvanized sheet and other galvanized products), followed by brass. In other words, zinc has many linkages to other substances. A dynamic model was used to look at these linkages of zinc to other substances in the production stage through other stages. In addition, dissipated zinc used in galvanized sheets and other galvanized products during the use stage was taken into account, using the results of previous atmospheric-exposure tests. Most discarded zinc is recovered as steel scrap or copper-alloy scrap. When used steel is remelted in an electric arc furnace (EAF), zinc is vaporized and collected as EAF dust. Therefore, this steel-associated zinc reenters the zinc cycle. By comparison, when zinc is used in copper alloys, zinc is not recycled and ends its life in the copper cycle. The mass balance of zinc as derived by our substance flow analysis was verified by comparing estimated values of the model with statistics and other estimates on zinc recovery. Using this model, zinc stocks in Japan was estimated to total approximately $3300 \mathrm{kt}$ at 2005 (26 kg/cap), or enough for around seven years. The amount of unrecovered zinc in 2005 was estimated at around $182 \mathrm{kt}$. Of this zinc loss, $73 \%$ went unrecovered in the steel cycle, e.g. it dissipated into the environment as sacrificial materials, or was in steel that was not collected for recycling.
\end{abstract}

KEY WORDS: dissipation; dynamic model; material flow analysis; substance flow analysis; zinc cycle.

\section{Introduction}

Zinc production in Japan amounted to about $600 \mathrm{kt}$ in 2005 , making it the third most important metal in tonnage terms after steel and copper. Approximately $60 \%$ of zinc production in Japan is used in the production of galvanized steel (galvanized sheet and other galvanized products), and the rest is used in the production of brass. ${ }^{1)}$ Zinc has many linkages with other substances, and these linkages have to be taken into consideration when accounting for the stock and flow of zinc in industry, and when estimating the potential for recycling zinc.

Substance flow analysis (SFA) is a useful tool for analyzing and estimating the flows of substances. Gordon et al. demonstrated the framework of a zinc flow model, simplifying the life cycles of zinc into four life stages, and expressed the zinc content of flows in the use stage and waste management stage. ${ }^{2)}$ Spatari et al. described the contemporary Europe zinc cycle for one year. ${ }^{3)}$ Zinc discarded from the use stage was estimated by categorizing waste into several groups, for which the concentrations of zinc were assumed. The study revealed that zinc was recovered mainly from zinc steel, steel dust, and die-cast parts from vehicles. Graedel et al. analyzed zinc stocks and flows throughout the world by dividing the world into eight religions. ${ }^{4}$ Van Beers et al. accounted for the stocks of zinc during the mid1990s in Australia and Oceania using the same model as
Spatari et al. ${ }^{5,6)}$

Hitherto, few attempts have been made to develop a comprehensive SFA model that takes into consideration the types of alloys in which zinc is used and which are discarded, and the mass of dissipation into the atmosphere and water during use. First, it would be useful to apply dynamic models to different types of alloys containing zinc. Spatari et al., Muller et al. and Daigo et al. used a dynamic model to calculate stocks of steel and copper. ${ }^{7-9)}$ Daigo et al. and Hatayama et al. applied the model to estimate the amount of steel and aluminum that would be discarded in the near future. ${ }^{10,11)}$ Using these results for steel and copper enables us to estimate the stock and discard of zinc used as galvanized steel products (entering to steel cycle) and brass (entering to copper cycle). In addition, conducting a large number of atmospheric-exposure tests would contribute to helping estimate losses of zinc dissipated into the atmosphere or water from the coating of galvanized steel products. In Sweden, Karlen et al. conducted tests on galvanized sheets. ${ }^{12)}$ Many tests also carried out at various places and in various climate conditions in Japan. ${ }^{13-17)}$

In this study, the SFA model described for zinc in Japan was conducted using a dynamic model that enables us to consider the linkages of zinc to other substances. In addition, the total amount for dissipative use in galvanized products was considered using the results of atmospheric- 


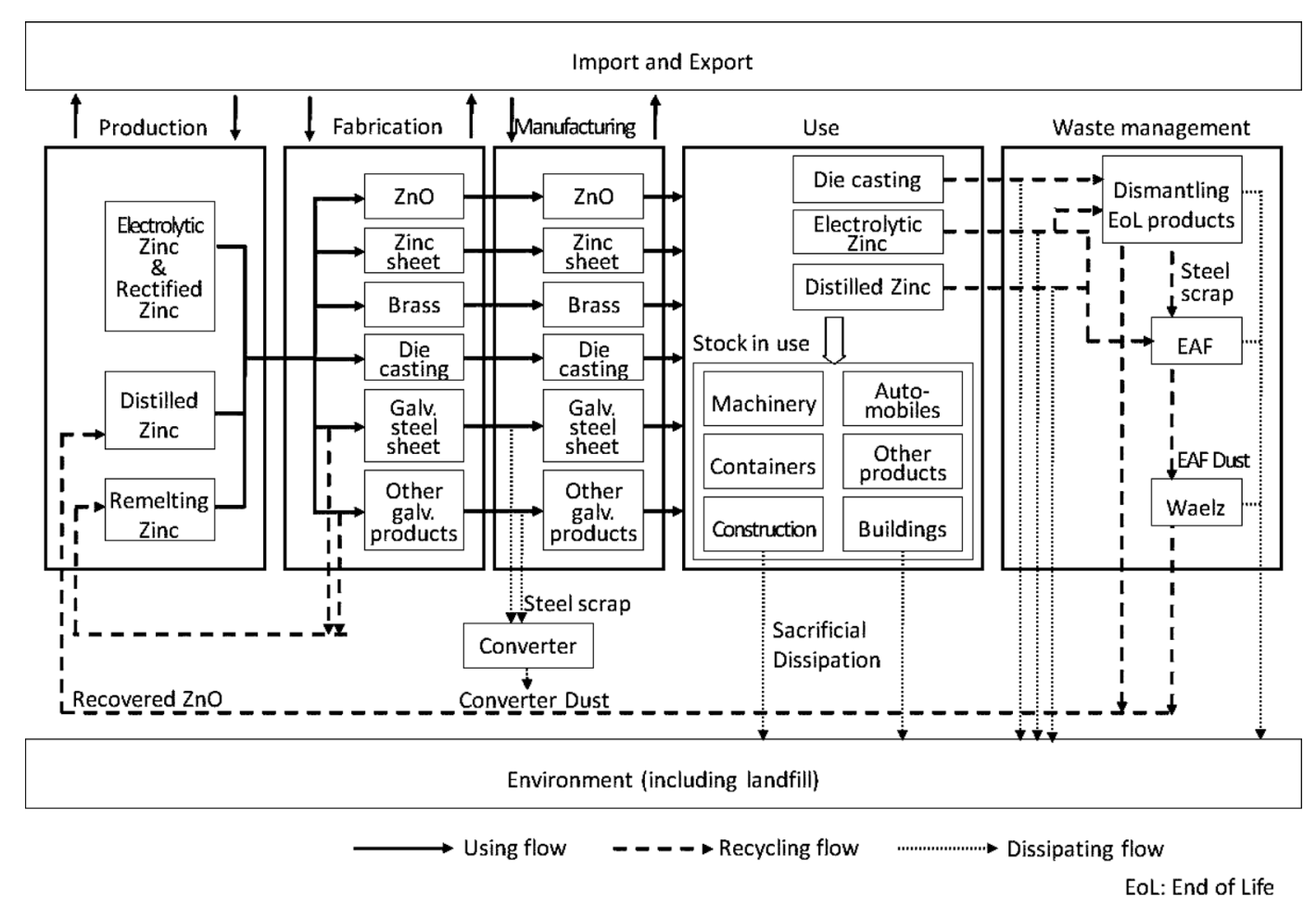

Fig. 1. Substance flow model for zinc.

exposure test data.

\section{Substance Flow Analysis for Zinc}

\subsection{Substance Flow Model for Zinc in Japan}

Figure 1 shows a schematic illustration of the substance flow model for zinc in Japan used in this study. The system boundaries of this model were defined as Japan in the year 2005 (with some flows and stocks estimated dynamically according to Sec. 2.4.2). In this model, we established five life cycle stages: production, fabrication, manufacturing, use, and waste management. In the fabrication stage, dissipated zinc before manufacturing of end-use products was taken into account. For example, when galvanized sheets are produced, zinc dissipates during the dipping process before the sheets are manufactured into actual finished products, such as for use in passenger vehicles and machines. In the manufacturing stage, yield loss when making finished products was considered. In the use stage, we estimated the stock of zinc in Japan. The stock of zinc was defined in this study as the amount of recyclable zinc that is contained in products in use; i.e., galvanized sheets, other galvanized products and die casting. While fabricated materials, brass, zinc oxide, zinc sheet and other products were counted in the production, fabrication and manufacturing stages, they were not added to the figure for zinc stocks as they are rarely recycled as zinc scrap or steel dust once they have been manufactured.

\subsection{Production}

Zinc metal is made from zinc ore, which contains lead $(\mathrm{Pb})$ or cadmium $(\mathrm{Cd})$ using dry or wet processes. In dry processes, distilled zinc is produced by the Imperial Smelter Process (ISP) and refined for high concentration. In the wet processes, electrolytic zinc is produced by sulfuric acid leaching and electrolysis. Remelting zinc is made from scrap generated during the fabrication stage. Production data for refined, electrolytic and remelting zinc are obtained from statistics. These statistics also provide figures for demand for zinc categorized by galvanized sheets, other galvanized products, die castings, brass, inorganic chemicals, and zinc sheets.

\subsection{Fabrication and Manufacturing}

In the fabrication process, zinc is fabricated into semifinished products, of which six types were taken into account: galvanized sheets, other galvanized products, die castings, brass, industrial inorganic chemicals, and zinc sheets. In the manufacturing process, zinc is made into end-use products, of which seven types were taken into account: construction, buildings, machines, passenger vehicles, trucks, containers, and other products.

\subsubsection{Fabrication}

Yield losses during galvanizing processes were estimated at $8 \%$ and $30 \%$ for galvanized sheet and other galvanized products, respectively. These figures were obtained by interviewing companies and specialists. Zinc scrap from the galvanizing process for galvanized sheet was assumed to be a raw material for refined zinc because it is high-purity metal, with little iron $(\mathrm{Fe})$ or aluminum $(\mathrm{Al})$. Zinc scrap from galvanizing process for other galvanized products is distinguished as "top dross" and "bottom dross". The former contains zinc metal and zinc oxide in about 50:50 ratio, and the latter contains zinc metal with a little $\mathrm{Fe}$ as an additive element. In this study, top dross was assumed not to be recycled as zinc metal, but to be recycled as zinc oxide for inorganic chemicals. Bottom dross was assumed to be recycled as a raw material for refined zinc. Yield loss during zinc die casting was estimated to be $0 \%$, based on inter- 
views; and scrap from zinc die castings was recovered only from end-use products. Zinc contained in brass or zinc alloys with copper, was assumed not to be recycled as zinc metal because these kinds of scrap are treated as copper alloys and recycled as copper materials. Industrial inorganic chemicals are used mostly as zinc oxides, which largely have applications in dissipative uses such as vulcanizing agents for automobile tires. They are rarely recycled-except for thermal recovery, so scrap materials from these sources were not considered as a potential source of recycled zinc metal. Consumption of zinc sheet, mostly used in batteries, is relatively small compared to other consumption purposes, so scrap from this source was not counted in this model.

\subsubsection{Manufacturing Finished Products}

Scrap from fabrication processes is called industrial scrap, which can be recycled into zinc metal. In this study, industrial scrap was assumed to be recovered from galvanized sheet, other galvanized products and zinc die castings. Industrial scrap from die castings was assumed not to be generated, based on the findings of interview surveys. Industrial scrap from galvanized sheet and other galvanized products is regarded as steel scrap. Therefore, this scrap is recycled as input material for basic oxygen furnaces (BOFs), EAFs, and in-house remelting processes. In this study, we assumed that all industrial steel scrap was input to BOFs, and that steel-associated zinc was reprocessed as BOF dust. Based on the findings of interview surveys, zinc in BOF dust was assumed to be rarely recycled as zinc metal. As a result of these assumptions, zinc recycling from industrial scrap was not counted in this study. This assigns considerable uncertainty to the study and further investigations are required to verify the accuracy of these assumptions.

\subsubsection{Allocating End-use Categories}

In this model, stock and discards of zinc were estimated dynamically using the Population Balance Model (PBM). ${ }^{18)}$ Lifetime distribution functions were set for each end-use product for use in the model. Input to the use stage by enduse was estimated as follows: Yield loss during fabrication processes was subtracted from the demand for semifinished products. In this way, consumption of semifinished products was estimated. This consumption was allocated to end-use categories and then yield loss during manufacturing processes was subtracted from the consumption for end uses.

Galvanized sheet and other galvanized products are counted as steel products. Therefore, yield loss during manufacturing processes ${ }^{19)}$ and lifetime distribution functions ${ }^{20)}$ were assumed to be the same as these studies on steel products.

In order to allocate the consumption of galvanized sheet to end-use categories, we multiplied consumption by the annual ratio of each end-use category and aggregated detailed end uses in the statistics on steel consumption. ${ }^{21) *}$ To allocate the consumption of other galvanized products to end-use categories we multiplied the consumption by the annual ratio of each end-use category by aggregating 12 end uses obtained from statistics on hot-dip galvanized steel products (see Table 1). ${ }^{22)}$ Consumption for die casting was allocated to end-use categories in the same way as previous ones, we then correlated consumption data on the six end uses from 1980 to 2005 .

Lifetime distribution functions were assumed to be the same as those for steel, because more than $50 \%$ of zinc die castings were used with steel in finished products. Corresponding end-use categories with statistical ${ }^{23)}$ categories in die casting are shown in Table 2.

Zinc used in steel products is utilized in finished products, some of which are traded as finished products. We could not obtain data for zinc trade, as was the case for finished products. In this study, this type of zinc trade is termed "indirect trade". Indirect trade as finished products from 1971 to 2000 was estimated based on indirect trade data for steel. We multiplied the consumption of each enduse category by the annual ratio of indirect trade of steel to

Table 1. Corresponding end-use category with statistical categories in hot-dip galvanized steel.

\begin{tabular}{|c|c|c|}
\hline \multirow{2}{*}{ End-use category } & \multicolumn{2}{|c|}{ Hot-dip galvanized products in statistics ${ }^{21)}$} \\
\hline & 1980-1995 & $1996-2006$ \\
\hline \multirow{6}{*}{ Construction } & Copper pipes & Copper pipes \\
\hline & Roads & Roads \\
\hline & Construction equipment & Construction equipment \\
\hline & Grating/Laths & Grating \\
\hline & Electric machines & Electric power equipment \\
\hline & Electric power equipment & - \\
\hline Buildings & Buildings/conservatories & Buildings \\
\hline \multirow{4}{*}{ Machines } & Ships & Ships \\
\hline & Cooling and heating & - \\
\hline & Ferrules & Ferrules \\
\hline & Rail vehicles & Rail vehicles \\
\hline Passenger vehicles & Ferrules & Ferrules \\
\hline Trucks & Ferrules & Ferrules \\
\hline Containers & - & - \\
\hline \multirow{3}{*}{ Other products } & Steel products & Steel products \\
\hline & Other products & Fasteners \\
\hline & - & Other products \\
\hline
\end{tabular}

Table 2. Corresponding end-use category with statistical categories in die casting.

\begin{tabular}{|l|l|}
\hline End-use category & Zinc alloys die casting in statistics ${ }^{22}$ \\
\hline Construction & - \\
\hline Buildings & - \\
\hline Machines & General machinery, Electrical machinery, Motorcycles \\
\hline Passenger vehicles & Automobiles \\
\hline Trucks & Automobiles \\
\hline Containers & - \\
\hline Other products & Other products \\
\hline
\end{tabular}

\footnotetext{
* Statistics are available for 1980 to 2006. Ratios before 1980 are assumed to be the same as those in 1980 . We do not take into account "shearing and slitting industry," "For further processing," or "Dealers" in the statistics, because their end uses cannot be categorized into end uses.
} 
Table 3. Runoff rate of zinc.

\begin{tabular}{|l|c|c|c|}
\hline & $\begin{array}{l}\text { Number of } \\
\text { samples }\end{array}$ & $\begin{array}{l}\text { Runoff rate obtained in } \\
\text { previous studies (g/m²/year) }\end{array}$ & $\begin{array}{l}\text { Estimated runoff rate used } \\
\text { in this study (wt\%/year) }\end{array}$ \\
\hline Inland areas & 21 & 12.5 & 2.27 \\
\hline $\begin{array}{l}\text { Coastal } \\
\text { areas }\end{array}$ & 11 & 22.9 & 4.2 \\
\hline
\end{tabular}

overall steel production by end uses. Indirect trade was then considered for the consumption of each end use, from which we estimated initial zinc usage.

\subsection{Use}

\subsubsection{Dissipative Zinc in the Use Stage}

Zinc dissipates into the environment when it has been applied to galvanized sheet and other galvanized products. In this paper, zinc dissipated in this fashion was estimated by using the results of atmospheric-exposure tests. They show that the runoff rate of zinc exposed to the atmosphere depends on location; inland areas (more than $1 \mathrm{~km}$ from a coastline) or coastal areas (less than $1 \mathrm{~km}$ from a coastline). ${ }^{13-17)}$ Therefore, we assumed that only "construction" and "buildings" are sources for zinc dissipation, because they are exposed to atmosphere directly, whereas the rest of end uses, such as machines or passenger vehicles, were assumed not to be exposed to the atmosphere. In addition, we assumed that they were used in inland areas because products used as "construction" or "buildings" were assumed to be used in urban areas, which are mostly located inland. Based on these assumptions, the runoff rate of zinc was estimated at $2.27 \%$ per year, assuming the total amount of galvanized steel was covered with $550 \mathrm{~g} / \mathrm{m}^{2}$ (Table 3).

\subsubsection{Dynamic Approach}

Discards of zinc were estimated using the PBM. ${ }^{18)}$ In this study, they were calculated by multiplying the previous years' inputs of each end-use category by each lifetime distribution. The average lifetime of products were set as follows: "construction", 34.5 years; "buildings", 28.9 years; "machines" and "other products", 12.1 years; while "passenger vehicles" and "trucks" were set annually using statistical data. The discards of zinc include dissipation during use. As shown at Sec. 2.1, the stock of zinc was assumed to be zinc that is contained in galvanized sheet, other galvanized products and die castings in use. It was estimated by accumulating time-series differences between annual inputs and discards of these products from the past to the present.

\subsection{Waste Management}

Recovered zinc was estimated by multiplying the discards of zinc obtained from the dynamic model by the collection rate of finished product by end-use categories. We assumed that the collection rates of zinc are the same as those of steel obtained from the previous study ${ }^{20)}$ because steel-associated zinc behaves as steel. Zinc dust collected at EAFs is recycled into secondary smelters and refiners by means of the Waelz process. Table 4 shows loss of zinc during recycling processes in Japan in 2005. ${ }^{24)}$
Table 4. Zinc losses during recycling processes.

\begin{tabular}{|l|c|c|}
\multicolumn{2}{c}{} & Unit: \% \\
\hline Process & Loss & Residual zinc \\
\hline Vaporization process in EAF & 0 & 100 \\
\hline Unrecovered dust (Landfill as EAF dust) & 35 & 65 \\
\hline The Waelz process & 6 & 59 \\
\hline
\end{tabular}

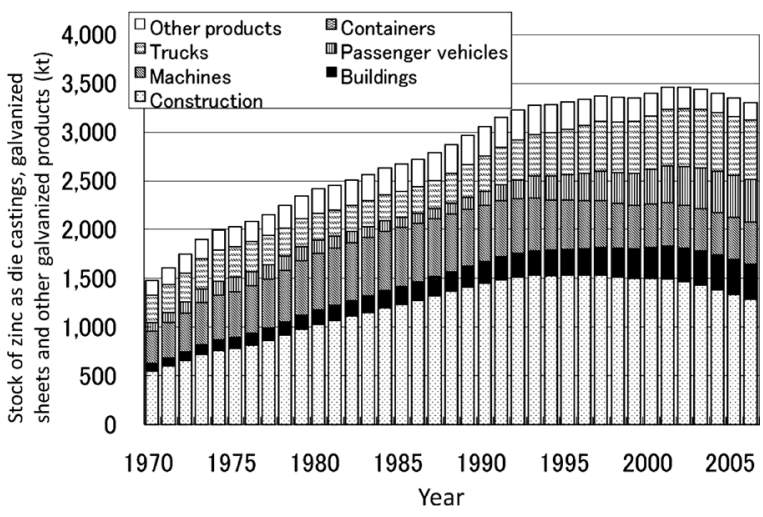

Fig. 2. Stock of zinc as die castings, galvanized sheets and other galvanized products.

\section{Results and Discussions}

\subsection{Results of Dynamic Analysis}

Historical zinc stock that is recyclable (as galvanized sheet, other galvanized products and die castings,) in Japan during 1980 to 2005 is shown in Fig. 2. It is estimated to have been $3300 \mathrm{kt}$ in 2006, which almost equals Japan's consumption requirements for seven years. It had increased gradually before the 1990s for every end-use category, but has recently decreased for construction and machine use. The long lifetime of constructions still leads to increase discards of zinc from constructions while consumption and stock of them have been already decreased.

The average citizen in Japan has a stockpile of $26 \mathrm{~kg} / \mathrm{cap}$ of zinc, which was derived by dividing the stock of zinc by the population of Japan. ${ }^{25}$ ) There is a discrepancy between the result and Australian zinc stock, $205 \mathrm{~kg} / \mathrm{cap}$, according to van Beers. It might be attributed to the different definitions of stock used in the two models. In this study, we estimated stock that can be recycled as metal, which means the stock of zinc oxide was ignored. Van Beers et al., however, defined stock as all the zinc in use stage and did not distinguish whether it would be recycled or not.

Figure 3 is a historical graph showing the result of the estimation for recovered zinc from EAF dust in Japan. The amount of recovered zinc rapidly increases until the 1980s, gradually increases, and then decreases to around $120 \mathrm{kt} /$ year. Recently, demand for zinc has decreased. Therefore, it is easy to see that recycled zinc estimates will decrease. We 


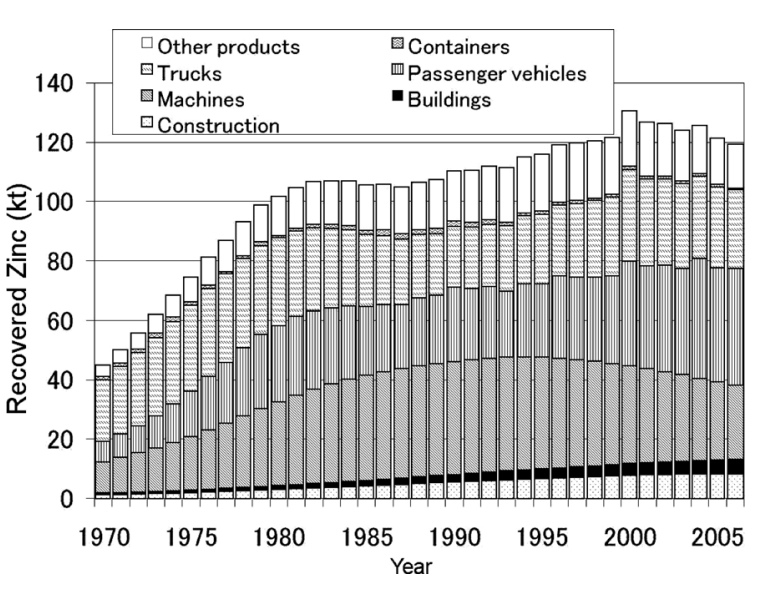

Fig. 3. Recovered zinc in Japan.

can see different trends in recycled zinc estimates among end-use categories. First, zinc recovered from passenger vehicles and trucks is likely to increase, which accounts for up to $50 \%$ of the total. One of the reasons comes from the increase in galvanized sheet demands for passenger vehicles and trucks. Second, zinc recovered from machines, however, tends to decrease as a result of the relatively large amount of indirect trade as finished products. Last, zinc recovered from construction and buildings is relatively small due to dissipation during use, and a poor collection rate$30 \%$ at the end of their lives.

Table 5 shows estimated losses of zinc by process in 2005. Total losses are nearly $182 \mathrm{kt} / \mathrm{year}$. Dissipated and unrecovered zinc as galvanized products; i.e., galvanized sheet and other galvanized products, total $132 \mathrm{kt} / \mathrm{year}$, which is approximately $73 \%$ of total losses. Thus, the losses are dominated by generation from steel-associated zinc, in other words, they vanish in the steel flows. In order to increase the total amount of recycled zinc, we need to improve the recycling rate of steel products and runoff rate of galvanized products.

\subsection{Verifying the Model}

In order to check the uncertainty of the estimates in this model, we compared them to other data, in the three flows listed below. The first flows are those at the fabrication stage and those at the manufacturing stage, we compared the estimates in this study to the figure obtained by statistics. ${ }^{1)}$ The other is the flow at the waste management stage, we compared the figures in this study to others using observation data.

\subsubsection{Verifying at Fabrication and Manufacturing Stages}

Figure 4 shows the result of a comparison between statistical $^{1)}$ and estimated remelting of zinc from 1980 to 2006. They are in good agreement around 1990 and from 2000 to 2005 , and are acceptable in other years. Note that there is some uncertainty among them because the estimates are inputs of the process, while the statistics are outputs of the process. Thus, the result is affected by the yield loss during the process of remelting zinc.

\subsubsection{Verifying at Waste Management Stage}

The input of EAF is verified by comparing estimates in this study to other estimates using observation data. The
Table 5. Zinc loss in 2005.

\begin{tabular}{|l|c|c|}
\hline & Loss (kt) & Loss (\%) \\
\hline Sacrificed & 94 & 52 \\
\hline Unrecovered steel products & 38 & 21 \\
\hline Landfilled EAF dust & 42 & 23 \\
\hline During the Waelz process & 8 & 4 \\
\hline Total & 182 & 100 \\
\hline
\end{tabular}

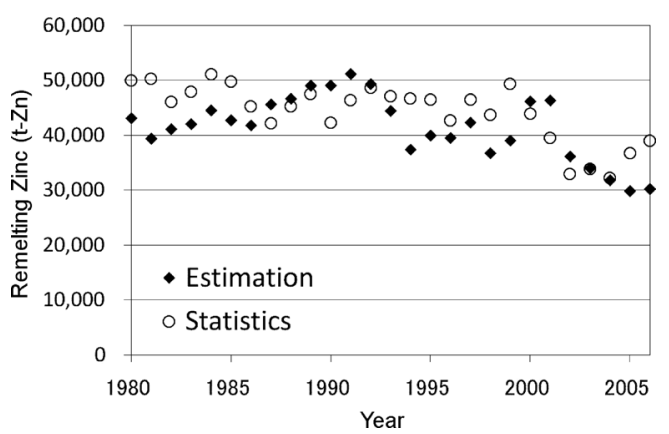

Fig. 4. Comparison between statistical and estimated remelting zinc.

Table 6. Zinc content in several samples of EAF dust.

\begin{tabular}{|l|l|}
\hline & Zinc \\
\hline Sotetsu Metal sample & $29 \%$ \\
\hline Sumitomo Metal Mining Shisaka Works Sample A & $18 \%$ \\
\hline Sumitomo Metal Mining Shisaka Works Sample B & $22 \%$ \\
\hline Sumitomo Metal Mining Shisaka Works Sample C & $21 \%$ \\
\hline Sumitomo Metal Mining Shisaka Works Sample D & $37 \%$ \\
\hline
\end{tabular}

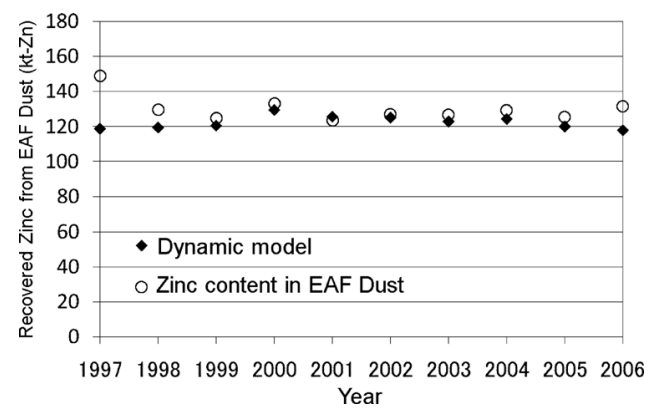

Fig. 5. Comparison of recovered zinc as EAF dust between estimate by the dynamic model and another estimate.

following describes how we estimate the input of EAF using observation data: A report shows that $15 \mathrm{~kg}$ of dust is generated from producing $1 \mathrm{t}$ of EAF steel on average. ${ }^{26)}$ Zinc content in EAF dust is monitored, and the amounts are published by some companies, which are representative factories using the Waelz process in $\operatorname{Japan}^{27,28)}$ (Table 6). Multiplying the production of EAF steel by the rate of dust generation $(15 \mathrm{~kg} / \mathrm{t}$-steel) historically, we estimate the annual generation of EAF dust. Next, by multiplying generation by the concentration of zinc in the dust, we can estimate the annual recovery of zinc from EAFs, which corresponds to the input of the EAFs. Figure 5 shows a comparison between an estimate by a dynamic model and that cal- 
culated in this section by the input of zinc into EAFs for a recent 10 -year period. They are in good agreement for the decade.

The output of the Waelz process is verified by comparing the estimate in this study to statistics. ${ }^{29)}$ Recycled zinc from the waste management stage is used for raw materials for distilled zinc. Narita et al. indicate that "other raw materials" of "distilled zinc" in production statistics means zinc recycled from EAF dust, which corresponds to outflow from the waste management stage in this study. ${ }^{30)}$ Therefore, we compare these statistics ${ }^{29}$ ) with our estimate in Fig. 6. While our estimate is a little higher than the statistics, it is at least of the same order of magnitude.

These results indicate that the estimates in this study are fairly acceptable. We should note, however, that uncertainties can be raised by assumptions regarding the collection rates of steel, rate of EAF dust generation, zinc content of EAF dust, and by omitting recycled zinc from industrial scrap.

\subsection{Substance Flow Analysis for Zinc in Japan in 2005}

Figure 7 shows substance flow for zinc throughout the entire-life stage in Japan in 2005. We analyzed substance flow for zinc in Japan by taking into consideration the linkages of zinc to other substances, steel and copper. We quan-

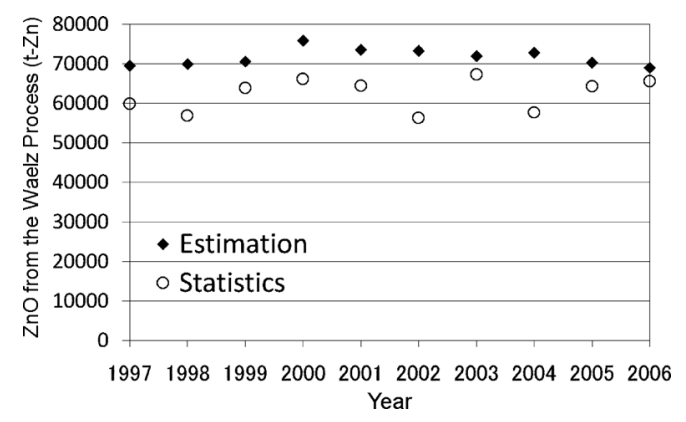

Fig. 6. Comparison between statistical and estimated zinc oxide generated from the Waelz process. tified two types of recycling flow: recycling dross generated from the fabrication stage for remelted zinc, and recycling scrap generated from the waste management stage for distilled zinc.

\section{Conclusion and Discussion}

This study analyzes the flows and stocks of zinc in Japan using a dynamic model-PBM. It demonstrates how to conduct a framework of SFA that considers the linkages of zinc to other substances, steel and copper. In addition, our analysis accounts for the amount of dissipative zinc in the use stage by using literature on exposure-atmospheric tests. Three flows in this model are verified by comparing them to statistical figures or observation data. The results show that the estimated figures in this model were acceptable.

SFA for zinc in Japan 2005 shows that the total amount of unrecovered zinc in the use stage and the waste management stage totals up to $182 \mathrm{kt} /$ year, and that approximately $73 \%$ of that is generated from steel-associated zinc. In order to increase the total amount of recycled zinc, we need to increase the recycling rate of steel products, and decrease the dissipation rate of galvanized products.

Although our SFA has been verified, there remains some uncertainty regarding the results. This arises from data limitation and assumptions made in estimates. Practical data or literature reported by producers would therefore improve the accuracy of the results.

\section{Acknowledgement}

We wish to thank Prof. Helmut Rechberger for his insightful comments and suggestions.

\section{REFERENCES}

1) Ministry of International Trade and Industry: Yearbook of Minerals and Non-ferrous Metals Statistics (1954-2005).

2) R. B. Gordon, T. E. Graedel, M. Bertram, K. Fuse, R. Lifset, H. Rechberger and S. Spatari: Resour. Conserv. Recyc., 39 (2003), 107.

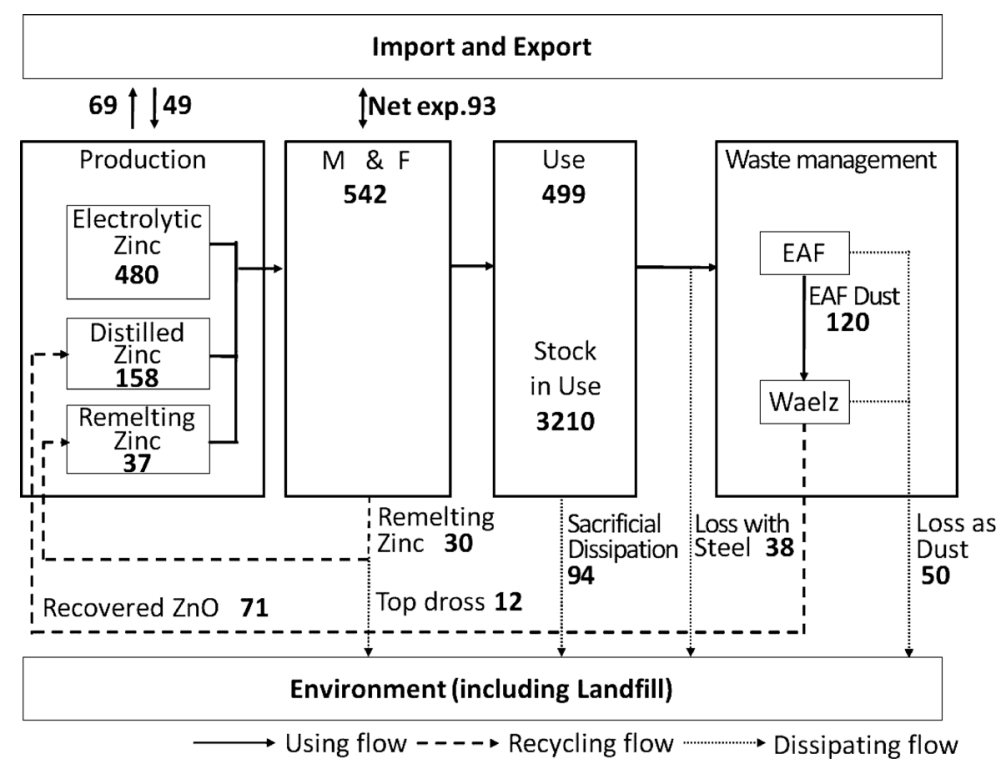

Fig. 7. Substance flow for zinc in Japan in 2005. Units of flows are kilo tons of zinc per year (kt/yr). Unit of stock used is kilo tones of zinc (kt). 
3) S. Spatari, M. Bertram, K. Fuse, T. E. Graedel and Eric Shelov: Resour. Conserv. Recycl., 39 (2003), 137.

4) T. E. Graedel, D. van Beers, M. Bertram, K. Fuse, R. B. Gordon, A. Gritsinin, E. M. Harper, A. Kapur, R. J. Klee, L. Memon and S. Spatari: J. Ind. Ecol., 9 (2005), 67.

5) D. van Beers, M. Bertram. K. Fuse, S. Spatari and T. E. Graedel: J. Master. Cycles Waste Manag., 6 (2004), 125.

6) D. van Beers and T. E. Graedel: J. Clean. Prod., 15 (2007), 849.

7) S. Spatari, M. Bertram, R. B. Gordon, K. Henderson and T. E. Graedel: Ecol. Econ., 54 (2005), 37.

8) D. B. Muller, T. Wang, B. Dubal and T. E. Graedel: Proc. Nat. Acad. Sci. USA, 103 (2006), 16111.

9) I. Daigo, Y. Igarashi, Y. Matsuno and Y. Adachi: ISIJ Int., 47 (2007), 1065.

10) I. Daigo, D. Fujimaki, Y. Matsuno and Y. Adachi: Tetsu-to-Hagané, 91 (2005), 171.

11) H. Hatayama, H. Yamada, I. Daigo, Y. Matsuno and Y. Adachi: Mater: Trans., 48 (2007), 2518.

12) C. Karlen, I. Odnevall Wallinder, D. Heijerick, C. Leygraf and C. R. Janssen: The Science of the Total Environment, 277 (2001), 169.

13) K. Yoshida, A. Suzuki and Y. Kitajima: J. Surf. Finish. Soc. Jpn., 21 (1970), 430.

14) I. Matsushima: J. Sur. Finish. Soc. Jpn., 31 (1980), 383.

15) Y. Togawa, K. Takahashi, T. Kanbe, S. Matsushita, K. Matsuo and T. Mishima: J. Sur. Finish. Soc. Jpn., 32 (1981).

16) Y. Hoboh: J. Sur. Finish. Soc. Jpn., 42 (1991), 160

17) Web site of Japan Lead Zinc Development Association: http:// www.jlzda.gr.jp/mekki/pdf/youyuu.pdf, Status: 2008/Apr/9

18) K. Yokota, Y. Matsuno, M. Yamashita and Y. Adachi: Int. J. LCA, 8
(2003), 129.

19) The Japan Ferrous Raw Materials Association: Quarterly Ferrous Raw Material Statistics, Tokyo, 24, (2005), 19.

20) Y. Igarashi, E. Kakiuchi, I. Daigo, Y. Matsuno and Y. Adachi: Tetsuto-Hagané, 93 (2007), 12.

21) The Japan Iron and Steel Federation: Iron and Steel Sales Statistics by End Uses and Regions, Tokyo.

22) Japan Mining Industry Association Lead Zinc Development Center: Lead and Zinc, Tokyo.

23) Ministry of International Trade and Industry, Research and Statistics Department Minister's Secretariat: Year book of machinery statistics (1954-2005).

24) Japan Mining Industry Association Lead Zinc Development Center: Zinc handbook, Tokyo, (1982).

25) Web site of Statistics Bureau: http://www.e-stat.go.jp/SG1/estat/List. do? bid=000000090004\&cycode $=0$, States: $2008 / \mathrm{Apr} / 9$.

26) The Japan Reserch and Development Center for Metals: kinzokukei niji sigen yuukou katsuyou bukai chousa houkokusyo kankyou no seiki ni mukete zero emissyon gata seizou purosesu no tenbou, Tokyo, (1996), 121.

27) H. Sugimoto, H. Takizawa and H. Ueda: J. MMIJ, 123 (2007), 723.

28) K. Nagai, Y. Matsumoto and H. Watanabe: J. MMIJ, 123 (2007), 726.

29) Minister of Economy, Trade and Industry, Agency for Natural Resources and Energy, Natural Resources and Fuel Department, Mineral and Natural Resources Division: Hitetsu kinzoku nado jukyuu geppou kinyuu youryou, Tokyo, (2005), 2.

30) N. Narita, M. Sagisaka and A. Inaba: Shigen-to-Sozai, 116 (2000), 674. 